\title{
Assessment of the Efficiency of Employment of the Communities' Resource Potential using Different Approaches
}

\author{
Roman Khirivskyi ${ }^{1}$, Ihor Yatsiv ${ }^{1}$, Liudmyla Petryshyn ${ }^{2}$, Tymofii Pasichnyk ${ }^{2}$, \\ Lesia Kucher $^{3}$, Inna Irtyshcheva ${ }^{4}$ \\ ${ }^{1}$ Lviv National Agrarian University, V. Velykoho, 1, Dubliany, 80381, Ukraine \\ ${ }^{2}$ Ivan Franko National University of Lviv, Universytetska, 1, Lviv, 79000, Ukraine \\ ${ }^{3}$ State Biotechnological University, Alchevskykh, 44, Kharkiv, 61002, Ukraine \\ ${ }^{4}$ Admiral Makarov National University of Shipbuilding, Tsentralnyi Ave. 3, Mykolaiv, 54000, Ukraine
}

\begin{abstract}
The paper presents the results of evaluation of the efficiency of employment of the communities' resource potential using different approaches on the example of Lviv region in Ukraine. The proposed methodology secures creation of a rational system of monitoring of the results of activities of amalgamated territorial communities (ATC) and determines what factorial indices should be improved and concerned by the communities' managers to conduct more efficient managerial work in the community. For example, in the communities with the budget that is sufficient to secure the increasing development of the community (Davydiv, Dubliany, Zabolottsi ATC), the primary focus can be done on the social development and growth of the infrastructural base, whereas in the ATCs with the low level of economic development (Volia-Baranetska, Lukiv, Mizhenets ATC), the most important task is to secure the sufficient extended growth of the population's income.
\end{abstract}

Keywords - resource potential, amalgamated territorial communities, efficiency, management.

DOI: $10.18421 /$ TEM111-46

https://doi.org/10.18421/TEM111-46

Corresponding author: Lesia Kucher,

State Biotechnological University, Kharkiv, Ukraine.

Email: kucher@btu.kharkov.ua

Received: 29 September 2021.

Revised: 03 February 2022.

Accepted: 10 February 2022.

Published: 28 February 2022.

(c) BY-NC-ND (C) 2022 Roman Khirivskyi et al; published by UIKTEN. This work is licensed under the Creative Commons Attribution-NonCommercial-NoDerivs 4.0 License.

The article is published with Open Access at https://www.temjournal.com/

\section{Introduction}

The reform of local government has set new tasks of development for the newly-established independent amalgamated territorial communities. Though the resource potential is a base for the territory development, the effective employment of the community's resources is the prerequisite for its development, and that key task is of great concern. The adequate analysis of the current conditions of amalgamated territorial communities (ATC), correlation of the potential effects from the community's resources use and the actually achieved ones, and the tendencies of changes of the main indices of the ATC activities is the precondition of their efficient performance.

The problems of effective employment of the ATC's resource potential have been studied by a great number of scientists in Ukraine. In particular, they are concerned in the works of V. Radović [1], I. Balaniuk et al. [2], I. Yatsiv et al. [3] etc. Among the recent publications on the topic, the works of L. Batsenko and V. Mantula [4], I. Chykarenko et al. [5], N. Goncharuk et al. [6], N. Patyka et al. [7], M. Misiuk and B. Bets [8], K. Patytska et al. [9], N. Popadynets et al. [10], Z. Siryk et al. [11], O. Skydan et al. [12], I. Storonyanska et al. [13], L. Horoshkova and Ie. Khlobystov [14], L. Umanets [15], G. Wright and S. Slukhai [16] are worth noting. The authors of the publications propose different methodic approaches to the assessment of the ATC development and employment of their resources. It is because of a great number of mathematical methods of assessment on one hand and insufficient statistical data because of the short period of the ATC performance on the other hand. 


\section{Materials and Methods}

The goal of the work is to continue the research on assessment of the ATC's resource potential on the example of the Lviv region in Ukraine in order to introduce recommendations on its efficient employment.

In the works [3], [17], different approaches are used to assess the efficiency of the resource potential employment by the communities of the Lviv region, particularly the method of normalized coefficients, method of complex variables and cluster analysis. In the work, it is suggested to continue the study on the efficiency of the resource potential employment by the communities of the Lviv region on the basis of those methods and to use the cluster method of least squares (MLS) for the comparative estimates. To assess the social and economic situation of amalgamated territorial communities, some indices of execution of the local budgets for 2016-2020 have been chosen [18], [19], [20], [21, p. 12].

\section{Results and Discussion}

The calculations of the indices of execution of the social and economic budgets of 22 amalgamated territorial communities of the Lviv region until 2020 are demonstrated in the work [17]. Table 1 supplies figures of the calculated indices in 2020.

Table 1. Indices of execution of the social and economic budgets of amalgamated territorial communities of the Lviv region in 2020

\begin{tabular}{|c|c|c|c|c|c|c|}
\hline № & Name of the ATC & $\begin{array}{l}\text { Index of } \\
\text { revenues to the } \\
\text { common fund per } \\
\text { one resident }\end{array}$ & $\begin{array}{c}\text { Index of the level } \\
\text { of budget } \\
\text { subsidization }\end{array}$ & $\begin{array}{c}\text { Index of expenses } \\
\text { for maintenance } \\
\text { of the } \\
\text { management } \\
\text { apparatus } \\
\end{array}$ & $\begin{array}{c}\text { Index of } \\
\text { expenses of the } \\
\text { common fund } \\
\text { per one resident }\end{array}$ & $\begin{array}{c}\text { Consolidated } \\
\text { index }\end{array}$ \\
\hline 1 & Babyna & 0.347 & 0.465 & 0.390 & 0.625 & 0.457 \\
\hline 2 & Biskovychi & 0.186 & 0.578 & 0.405 & 0.358 & 0.382 \\
\hline 3 & Vilshana & 0.112 & 0.758 & 0.604 & 0.407 & 0.470 \\
\hline 4 & Volia-Baranetska & 0.005 & 0.969 & 0.931 & 0.180 & 0.521 \\
\hline 5 & Hnizdychiv & 0.267 & 0.285 & 0.156 & 0.169 & 0.219 \\
\hline 6 & Hrabovets & 0.170 & 0.573 & 0.680 & 0.163 & 0.397 \\
\hline 7 & Davydiv & 1.000 & 0.032 & 0.069 & 0.606 & 0.427 \\
\hline 8 & Dubliany & 0.726 & 0.275 & 0.000 & 0.868 & 0.467 \\
\hline 9 & Zhovtantsi & 0.592 & 0.000 & 0.054 & 0.703 & 0.337 \\
\hline 10 & Zabolottsi & 0.716 & 0.122 & 0.097 & 1.000 & 0.484 \\
\hline 11 & Lukiv & 0.027 & 0.921 & 0.672 & 0.204 & 0.456 \\
\hline 12 & Mizhenets & 0.044 & 0.860 & 1.000 & 0.168 & 0.518 \\
\hline 13 & Mostyska & 0.356 & 0.243 & 0.057 & 0.402 & 0.265 \\
\hline 14 & Nyzhankovychi & 0.193 & 0.502 & 0.429 & 0.360 & 0.371 \\
\hline 15 & Novyi Kalyniv & 0.631 & 0.000 & 0.231 & 0.491 & 0.339 \\
\hline 16 & Nove Misto & 0.000 & 1.000 & 0.693 & 0.000 & 0.423 \\
\hline 17 & Novi Strilyshcha & 0.250 & 0.504 & 0.360 & 0.452 & 0.392 \\
\hline 18 & Sudova Vyshnia & 0.214 & 0.560 & 0.275 & 0.413 & 0.366 \\
\hline 19 & Trostianets & 0.607 & 0.225 & 0.127 & 0.578 & 0.384 \\
\hline 20 & Khodoriv & 0.318 & 0.385 & 0.120 & 0.422 & 0.311 \\
\hline 21 & Chukva & 0.119 & 0.678 & 0.646 & 0.430 & 0.468 \\
\hline 22 & Shehyni & 0.399 & 0.130 & 0.202 & 0.363 & 0.274 \\
\hline
\end{tabular}

Source: composed by the authors based on the results of monitoring of the local budgets execution [20] and formulas (1), (2) [17].

Table 1 demonstrates that among the amalgamated territorial communities of the Lviv region, the best indices of organization of the social and economic budgets execution in 2020 were achieved by VoliaBaranetska and Mizhenets ATC with the values of the index equal to 0.521 and 0.518 respectively. Volia-Baranetska and Mizhenets ATC implemented their financial leverage within the frames of $52 \%$. A rather high level of execution of the social and economic budgets was organized in Zabolottsi ATC
$-48 \%$, Vilshana, Dubliany and Chukva ATC $-47 \%$, Babyna ATC $-46 \%$. Comparing the amalgamated territorial communities of the Lviv region, the most problems were marked in the social and economic development of Hnizdychiv ATC - 22\%.

Figure 1 presents consolidated indices of execution of the social and economic budgets of amalgamated territorial communities of the Lviv region in 20162020. The numbers in the figure stand for the ATC names referring to Table 1 . 


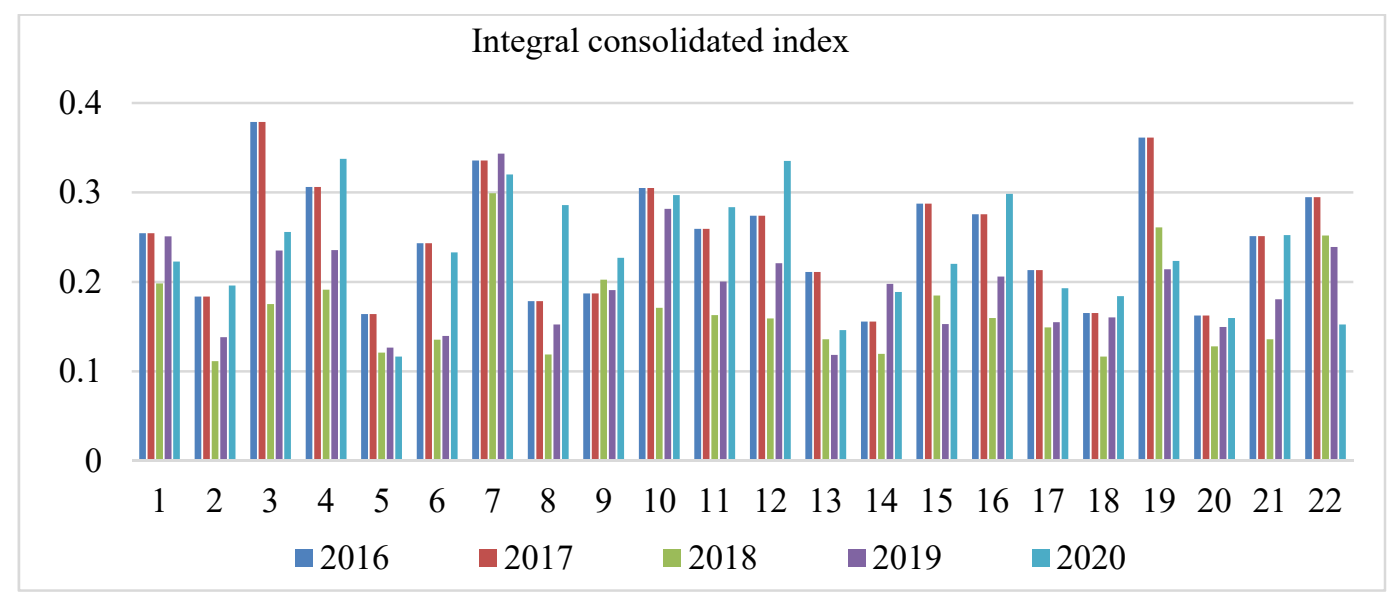

Figure 1. Consolidated indices of amalgamated territorial communities of the Lviv region in 2016-2020 Source: built by the authors.

Figure 1 demonstrates the permanent and rather high integral consolidated index in Davydiv ATC as compared to other communities, and one of the smallest consolidated indices for the last three years, i.e., in Hnizdychiv ATC.

The overall consolidated index of execution of the social and economic budgets of amalgamated territorial communities of the Lviv region in 20162020 is presented in the Table 2.

Table 2. Overall consolidated index of execution of the social and economic budgets of amalgamated territorial communities of the Lviv region in 2016-2020

\begin{tabular}{|c|c|c|c|c|c|}
\hline Year & 2016 & 2017 & 2018 & 2019 & 2020 \\
\hline $\begin{array}{c}\text { Overall consoli- } \\
\text { dated index }\end{array}$ & 0.420 & 0.420 & 0.194 & 0.341 & 0.397 \\
\hline
\end{tabular}

Table 2 confirms that 2018 was difficult for amalgamated territorial communities of the Lviv region in terms of execution of the social and economic budgets, but since that year, the situation has been improving.

To assess the dynamics of the level of social and economic development of ATC in that terms, the static and dynamic integral estimates were made [17].

Values of the dynamic integral estimate of stability of the social and economic development of amalgamated territorial communities of the Lviv region are demonstrated in Figure 2.

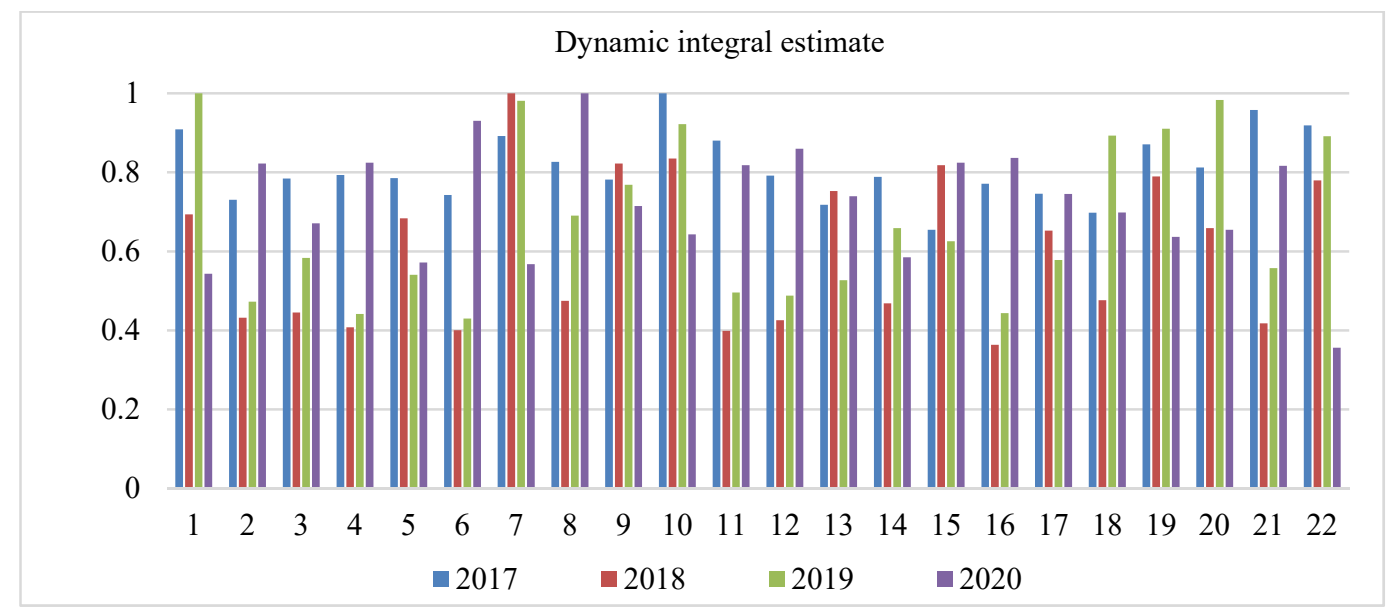

Figure 2. Dynamic integral estimate of stability of development of the amalgamated territorial communities of the Lviv region in 2017-2020. Source: built by the authors.

Figure 2 shows that in the last three years, the dynamics of development of the social and economic indices of nine ATCs has increased. Particularly, they are Biskovychi, Volia-Baranetska, Hrabovets ATC. The dynamics of above $60 \%$ is demonstrated by development of the social and economic indices of Zhovtantsi, Zabolottsi, Novyi Kalyniv, Trostianets and
Khodoriv ATC. In 2020, development of the social and economic indices of Davydiv ATC was slowed down.

The consolidated dynamic integral estimate of the social and economic development of ATC (formula (6) [17], presented in Figure 3, is the modification of the models of integral estimate of advantages of the objects for investing. 


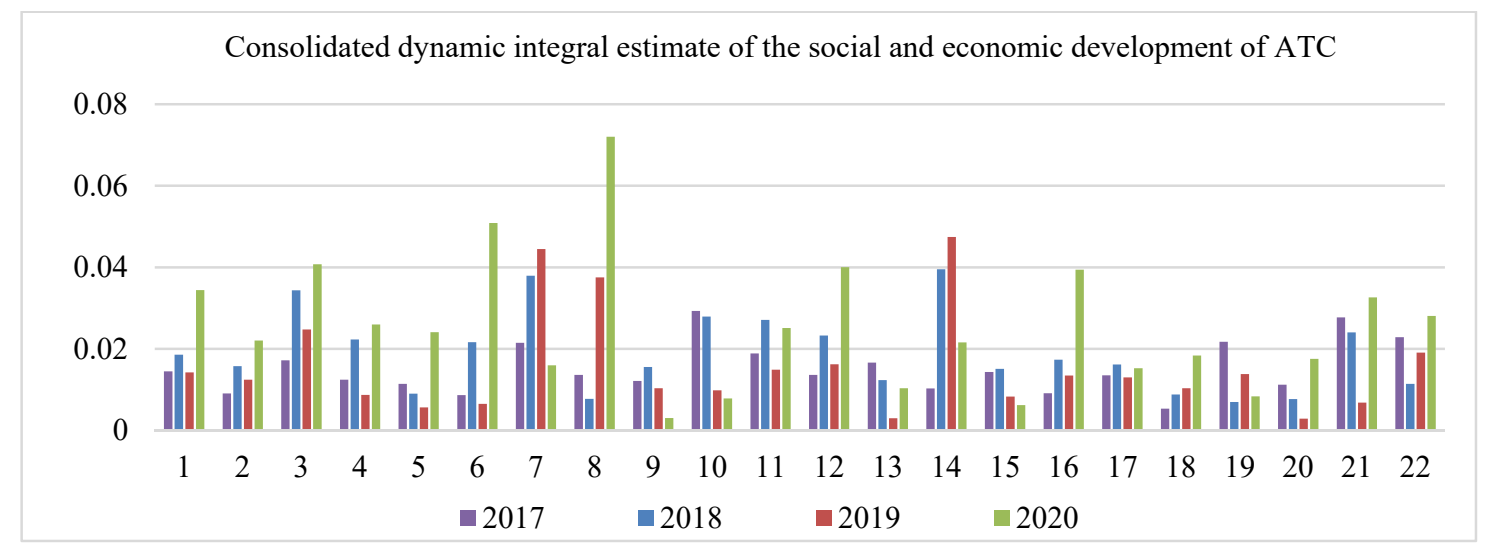

Figure 3. Consolidated integral estimate of stability of development of the amalgamated territorial communities of the Lviv region in 2017-2020. Source: built by the authors.

Figure 3 shows that Hrabovets and Dubliany ATC are currently more-attractive for investors than other amalgamated territorial communities. However, in all studied ATCs, that index is not high and unattractive for investing.

In the work [3], the pairwise comparison of different resultant and factorial indices was conducted using the method of normalized coefficients and the BCG-matrix (Boston Consulting Group matrix). In particular, it provided results on the position of each community concerning the density of population, working capacity resource of the amalgamated territorial communities, rating indices of the comparison of social public formations, and assessment of the expenses for maintenance of the management apparatus of each community. Most of the indices have not significantly changed during the last years. However, financial indices are changed each year.

In 2020, the correlation of revenues and expenses of the common fund per one resident is demonstrated in Figure 4.

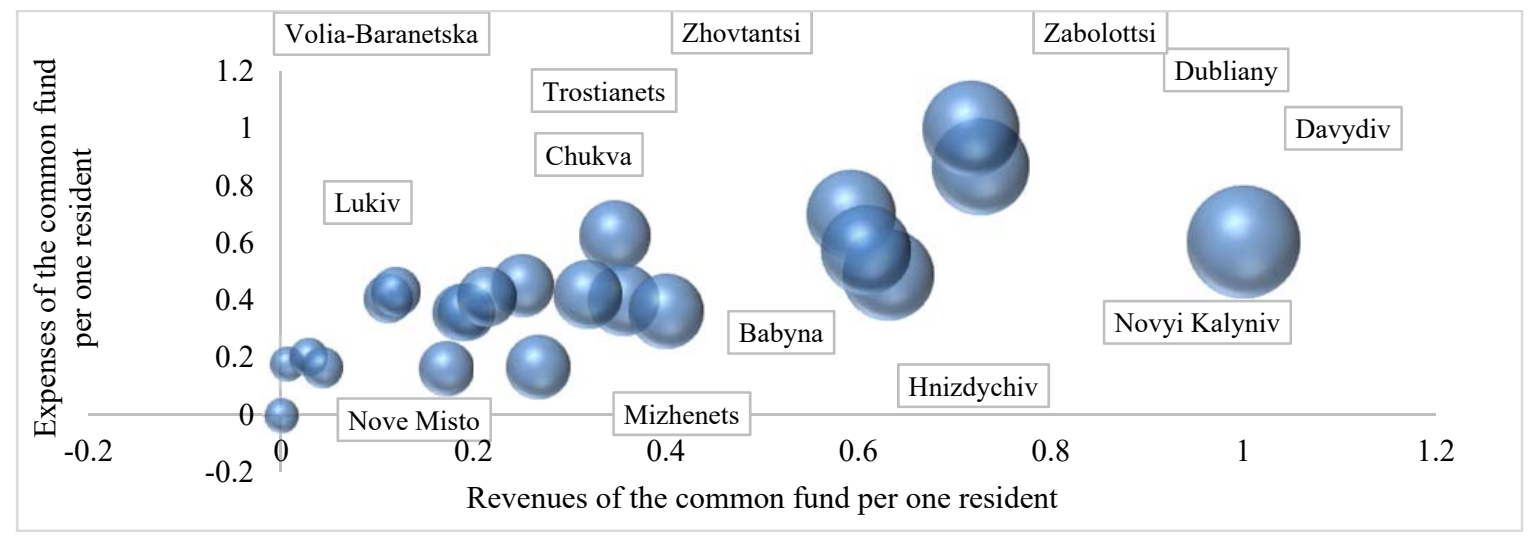

Figure 4. Comparison of the indices of "Revenues - expenses of the common fund per one resident" Source: built by the authors.

The figure characterizes the financial potential of the ATC, capacity to supply the community due to its own resources, and expedience of their use. In particular, among the studied ATCs, the highest revenues to the common fund per one resident are marked in Davydiv ATC, whereas the best balanced revenues-expenses ratio - in Dubliany ATC. The excess expenses of the common fund per one resident correlating to the revenues are observed, for example, in Chukva, Babyna, Zhovtantsi ATC. It confirms the prospective development of the community on one hand, or the inefficient use of the funds on the other hand.

Figure 5. gives comparison of the indices of expenses of the common fund correlating to the expenses for maintenance of the management apparatus. The figure shows that contrary to Dubliany, Zhovtantsi, Zabolottsi ATC, such communities as Novyi Kalyniv, Davydiv, Hrabovets spend more money for maintenance of the management apparatus than for the community development.

Figures 4. and 5. demonstrate complicated financial conditions of Nove Misto ATC, and therefore, according to the resolution of the Cabinet of Ministers of Ukraine of June 12, 2020, № 718-p "On determination of the administrative centers and approval of the area of territorial communities of the Lviv region", Nove Misto ATC is included into Dobromyl ATC. 


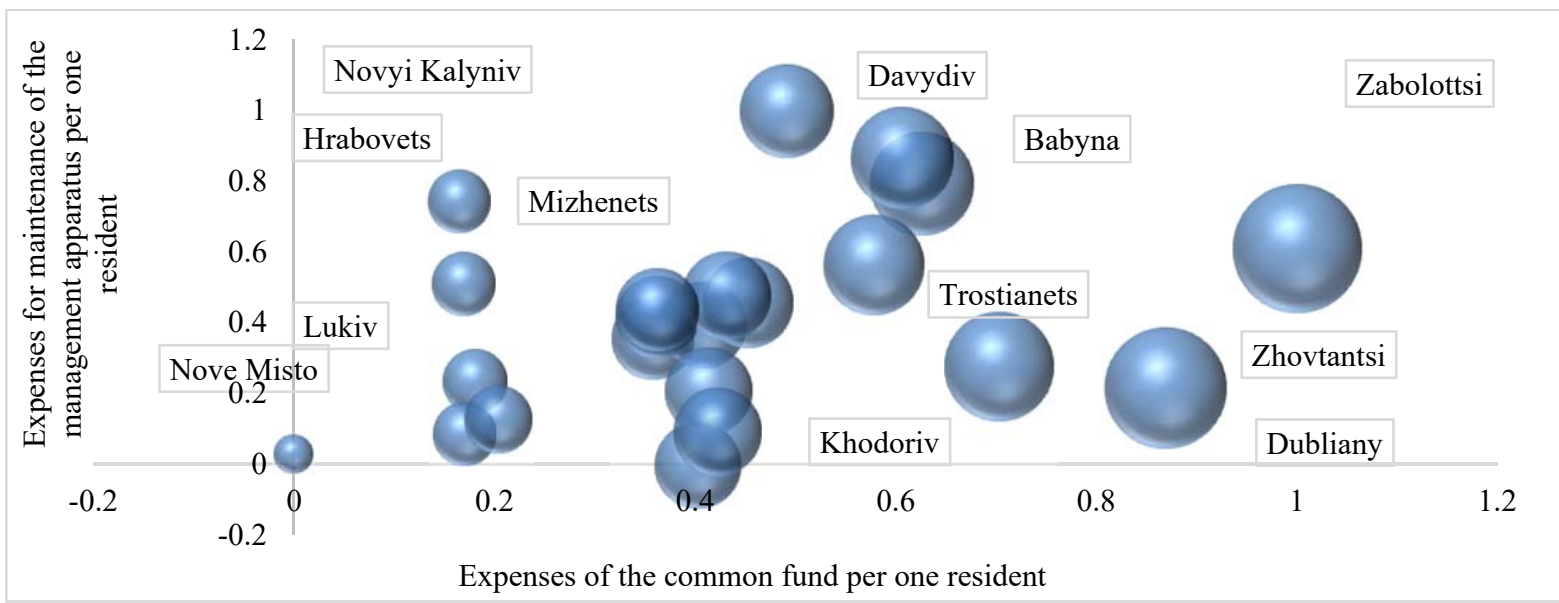

Figure 5. Comparison of the indices of expenses of the common fund correlating to the expenses for maintenance of the management apparatus. Source: built by the authors.

Based on the theory of the functions of complex variables, one of our previous works presents estimates of the efficiency of use of the funds of communities in the Lviv region until 2020, and therefore, makes a forecast of the own revenues per one resident and the share of expenses for maintenance of the management apparatus in each of the studied ATCs at the end of 2020. Table 3 presents a comparative analysis of the forecast and the actual data of 2020 .

Table 3. Expected and actual values of the indices of amalgamated territorial communities of the Lviv region in 2020

\begin{tabular}{|c|c|c|c|c|c|c|c|c|}
\hline $\begin{array}{c}\text { ATC of the Lviv } \\
\text { region }\end{array}$ & \begin{tabular}{|c|} 
Expected \\
own \\
revenues \\
per one \\
resident \\
$(\%)$ \\
\end{tabular} & $\begin{array}{l}\text { Actual } \\
\text { own } \\
\text { revenues } \\
\text { per one } \\
\text { resident } \\
(\%)\end{array}$ & $\begin{array}{c}\text { Absolute } \\
\text { deviation } \\
\text { of the } \\
\text { forecast } \\
(\%)\end{array}$ & $\begin{array}{l}\text { Relative } \\
\text { deviation } \\
\text { of the } \\
\text { forecast }\end{array}$ & $\begin{array}{l}\text { Expected share } \\
\text { of expenses for } \\
\text { maintenance } \\
\text { of the } \\
\text { management } \\
\text { apparatus }(\%)\end{array}$ & $\begin{array}{c}\text { Actual share of } \\
\text { expenses for } \\
\text { maintenance of } \\
\text { the } \\
\text { management } \\
\text { apparatus }(\%)\end{array}$ & $\begin{array}{c}\text { Absolute } \\
\text { deviation } \\
\text { of the } \\
\text { forecast } \\
(\%)\end{array}$ & $\begin{array}{l}\text { Relative } \\
\text { deviation } \\
\text { of the } \\
\text { forecast }\end{array}$ \\
\hline Babyna & 15.40 & 5.59 & 9.81 & 1.76 & 71.18 & 19.77 & 51.41 & 2.60 \\
\hline Biskovychi & 0.06 & 3.02 & 2.96 & 0.98 & 56.70 & 15.70 & 41.00 & 2.61 \\
\hline Vilshana & 0.48 & 1.84 & 1.37 & 0.74 & 91.02 & 16.45 & 74.58 & 4.53 \\
\hline Volia-Baranetska & 0.05 & 0.15 & 0.09 & 0.65 & 118.12 & 12.97 & 105.15 & 8.11 \\
\hline Hnizdychiv & 6.11 & 4.31 & 1.81 & 0.42 & 21.90 & 12.81 & 9.09 & 0.71 \\
\hline Hrabovets & 1.58 & 2.78 & 1.20 & 0.43 & 63.17 & 12.72 & 50.45 & 3.97 \\
\hline Davydiv & 16.12 & 15.97 & 0.14 & 0.01 & 22.61 & 19.48 & 3.14 & 0.16 \\
\hline Dubliany & 5.71 & 11.61 & 5.89 & 0.51 & 41.24 & 23.49 & 17.75 & 0.76 \\
\hline Zhovtantsi & 15.57 & 9.49 & 6.09 & 0.64 & 4.72 & 20.97 & 16.25 & 0.77 \\
\hline Zabolottsi & 15.80 & 11.46 & 4.34 & 0.38 & 27.37 & 25.50 & 1.86 & 0.07 \\
\hline Lukiv & 0.06 & 0.50 & 0.43 & 0.87 & 64.90 & 13.34 & 51.56 & 3.87 \\
\hline Mizhenets & 0.28 & 0.76 & 0.48 & 0.63 & 133.14 & 12.79 & 120.35 & 9.41 \\
\hline Mostyska & 10.69 & 5.73 & 4.96 & 0.87 & 24.81 & 16.37 & 8.44 & 0.52 \\
\hline Nyzhankovychi & 1.67 & 3.13 & 1.46 & 0.47 & 50.88 & 15.73 & 35.15 & 2.23 \\
\hline Novyi Kalyniv & 10.54 & 10.11 & 0.43 & 0.04 & 39.43 & 17.73 & 21.70 & 1.22 \\
\hline Nove Misto & 0.16 & 0.07 & 0.10 & 1.45 & 66.47 & 10.22 & 56.25 & 5.50 \\
\hline Novi Strilyshcha & 5.95 & 4.04 & 1.91 & 0.47 & 35.96 & 17.13 & 18.83 & 1.10 \\
\hline Sudova Vyshnia & 3.07 & 3.47 & 0.39 & 0.11 & 33.86 & 16.54 & 17.32 & 1.05 \\
\hline Trostianets & 19.30 & 9.72 & 9.58 & 0.99 & 24.38 & 19.05 & 5.32 & 0.28 \\
\hline Khodoriv & 9.87 & 5.12 & 4.75 & 0.93 & 12.26 & 16.67 & 4.40 & 0.26 \\
\hline Chukva & 0.18 & 1.95 & 1.77 & 0.91 & 69.68 & 16.80 & 52.88 & 3.15 \\
\hline Shehyni & 10.66 & 6.42 & 4.24 & 0.66 & 26.42 & 15.77 & 10.65 & 0.68 \\
\hline
\end{tabular}

Source: interpretation of works [3], [17].

Table 3 demonstrates a satisfactory forecast of the share of expenses for maintenance of the management apparatus except for Vilshana, VoliaBaranetska and Mizhenets ATC, as well as rather good forecast of the own revenues per one resident in all ATCs of the Lviv region.

For comparison, a similar forecast is made using the method of least squares, and the obtained results are given in Table 4. 
Table 4. Linear function of regression of the indices of amalgamated territorial communities of the Lviv region in 2020 and deviations of its extrapolation

\begin{tabular}{|c|c|c|c|c|c|c|c|c|}
\hline \multirow[b]{2}{*}{ ATC of the Lviv region } & \multicolumn{4}{|c|}{ own revenues per one resident $(\%)$} & \multicolumn{4}{|c|}{$\begin{array}{l}\text { share of expenses for maintenance of the } \\
\text { management apparatus }\end{array}$} \\
\hline & $\mathrm{a}_{0}$ & $a_{1}$ & $\begin{array}{c}\text { Absolute } \\
\text { deviation } \\
\text { of the } \\
\text { forecast } \\
(\%)\end{array}$ & $\begin{array}{l}\text { Relative } \\
\text { deviation } \\
\text { of the } \\
\text { forecast }\end{array}$ & $a_{0}$ & $a_{1}$ & $\begin{array}{c}\text { Absolute } \\
\text { deviation } \\
\text { of the } \\
\text { forecast } \\
(\%)\end{array}$ & $\begin{array}{l}\text { Relative } \\
\text { deviation } \\
\text { of the } \\
\text { forecast }\end{array}$ \\
\hline Babyna & 0.56 & -0.82 & 34.09 & 6.10 & 0.68 & -1.21 & 26.53 & 1.34 \\
\hline Biskovychi & 0.29 & -0.47 & 18.40 & 6.09 & 0.51 & -0.84 & 18.23 & 1.16 \\
\hline Vilshana & 0.48 & -0.58 & 37.07 & 20.12 & 0.84 & -1.72 & 19.61 & 1.19 \\
\hline Volia-Baranetska & 0.16 & -0.16 & 13.70 & 93.73 & 0.93 & -4.44 & 13.62 & 1.05 \\
\hline Hnizdychiv & -0.43 & 2.23 & 18.60 & 4.32 & 0.19 & 0.45 & 10.88 & 0.85 \\
\hline Hrabovets & -1.11 & 2.07 & 87.88 & 31.65 & 0.54 & 0.41 & 11.59 & 0.91 \\
\hline Davydiv & 0.51 & -1.02 & 15.64 & 0.98 & 0.29 & -0.09 & 20.93 & 1.07 \\
\hline Dubliany & 0.76 & -1.82 & 21.92 & 1.89 & 0.40 & -0.35 & 27.59 & 1.17 \\
\hline Zhovtantsi & 0.53 & -1.71 & 7.29 & 0.77 & 0.21 & 0.00 & 20.99 & 1.00 \\
\hline Zabolottsi & -0.98 & 4.10 & 4.91 & 0.43 & 0.24 & 0.24 & 22.71 & 0.89 \\
\hline Lukiv & 0.16 & -0.21 & 12.82 & 25.81 & 0.70 & -2.18 & 14.42 & 1.08 \\
\hline Mizhenets & 0.25 & -0.28 & 20.51 & 26.90 & 0.90 & -3.63 & 15.56 & 1.22 \\
\hline Mostyska & 0.72 & -2.99 & 17.18 & 3.00 & 0.24 & -0.30 & 18.11 & 1.11 \\
\hline Nyzhankovychi & 0.32 & -0.53 & 20.59 & 6.57 & 0.56 & -1.30 & 19.80 & 1.26 \\
\hline Novyi Kalyniv & 1.29 & -3.35 & 59.88 & 5.92 & 0.38 & -0.26 & 20.35 & 1.15 \\
\hline Nove Misto & 0.20 & -0.30 & 17.23 & 258.05 & 0.63 & -1.77 & 10.34 & 1.01 \\
\hline Novi Strilyshcha & 1.38 & -3.13 & 80.65 & 19.98 & 0.43 & -0.26 & 18.18 & 1.06 \\
\hline Sudova Vyshnia & 0.44 & -1.10 & 22.25 & 6.42 & 0.39 & -0.79 & 19.28 & 1.17 \\
\hline Trostianets & 0.95 & -3.22 & 24.17 & 2.49 & 0.29 & -0.29 & 21.88 & 1.15 \\
\hline Khodoriv & 0.54 & -1.97 & 16.18 & 3.16 & 0.25 & -0.34 & 18.40 & 1.10 \\
\hline Chukva & 0.19 & -0.23 & 13.35 & 6.84 & 0.62 & -0.30 & 17.38 & 1.03 \\
\hline Shehyni & 0.85 & -2.21 & 43.35 & 6.75 & 0.33 & -0.18 & 16.93 & 1.07 \\
\hline
\end{tabular}

Source: composed by the authors.

Data in Table 4 confirm that the linear extrapolation of the method of least squares provides worse results as compared to the method of complex variables. Unsatisfactory results were obtained also under the extrapolation by the exponent function. Moreover, the function of complex variables provides a forecast simultaneously by two parameters of the research, whereas the method of least squares - only extrapolates the dependent variable under the set value of the independent one.

\section{Conclusions}

The proposed methodology secures creation of a rational system of monitoring of the results of ATC activities and determines what factorial indices should be improved and concerned by the communities' managers to conduct more efficient managerial work in the community. For example, in the communities with the budget that is sufficient to secure the increasing development of the community (Davydiv, Dubliany, Zabolottsi ATC), the primary focus can be done on the social development and growth of the infrastructural base, whereas in the ATCs with the low level of economic development (Volia-Baranetska, Lukiv, Mizhenets ATC), the most important task is to secure the sufficient extended growth of the population's income. The research demonstrates that particularly in Davydiv, Hnizdychiv ATC, a considerable attention should be paid to development of the healthcare sphere, whereas Zhovtantsi, Velykyi Liubin and Trostianets ATC have favorable conditions for employment of their labor potential.

One of the key difficulties of the presented research is in the deficit of information to make a forecast of the indices of the ATCs' efficiency by using the method of complex variables. Therefore, the prospects of the further investigation suggest development of the proposals on improvement of the information supply for the process of assessment of the efficiency of use of the communities' resource potential by applying different approaches. 


\section{References}

[1]. Radović, V. (2016). Mitigation efforts in rural communities after extreme weather events-new insights for stakeholders. Journal of Innovations and Sustainability, 2(3), 37-56.

[2]. Balaniuk, I., Kozak, I., Balaniuk, S., KozakBalaniuk, I., Sas, L., \& Shelenko, D. (2021). The role of united territorial communities in the functioning of agricultural enterprises. Management theory and studies for rural business and infrastructure development, 2021, vol. 43, no. 1, p. 52-66. https://doi.org/10.15544/mts.2021.05

[3]. Yatsiv, I., Khirivskyi, R., Pasichnyk, T., Petryshyn, L., \& Kucher, L. (2019). Assessment of the efficiency of resource potential employment by the communities of Lviv region of Ukraine. European Journal of Sustainable Development, 8(2), 165-165. https://doi.org/10.14207/ejsd.2019.v8n2p165

[4]. Batsenko, L. \& Mantula, V. (2019). Estimation of resource potential of the united territorial community. Evropský časopis ekonomiky a managementu, 5(1), 242-255.

[5]. Chykarenko, I. A., Mamatova, T. V., Sergienko, E. O., Chykarenko, O. O., \& Martseniuk, O. O. (2020). Organizational and legal aspects of elaboration of amalgamated territorial communities sustainable development strategies. International Journal of Management, 11(5), 1084-1093. https://doi.org/10.34218/IJM.11.5.2020.099

[6]. Goncharuk, N. T., Prokopenko, L. L., Krushelnytska, T. A., Rubchak, O. B., \& Taraban, S. V. (2021). The capability of amalgamated territorial communities as a key factor in the socio-economic development of territories. Studies of Applied Economics, 39(6). https://doi.org/10.25115/eea.v39i6.5267

[7]. Patyka, N., Gryschenko, O., Kucher, A., Hełdak, M., \& Raszka, B. (2021). Assessment of the Degree of Factors Impact on Employment in Ukraine's Agriculture. Sustainability, 13(2), 564. https://doi.org/10.3390/su13020564.

[8]. Misiuk, M. V., \& Betz, B. B. (2019). Methodological Approach to Assessing the use of Resource Efficiency of the United Territorial Communities. Innovative Economy, (3-4), 100-107.

[9]. Patytska, K., Panukhnyk, O., Popadynets, N., \& Kramarenko, I. (2021). Forming the Territorial Communities' Local Budgets in Ukraine Under Decentralization: Current Condition and Management Tasks. Journal of Optimization in Industrial Engineering, 14(2), 23-30.

https://doi.org/10.22094/JOIE.2020.677868

[10]. Popadynets, N., Patytska, K. \& Leshchukh, I. (2019). Current problems of the use of natural resources capacity of territorial communities in Ukraine in conditions of decentralization. Socioeconomic problems of the modern period of Ukraine, 3(137), 3-9.

https://doi.org/10.36818/2071-4653-2019-3-1.
[11]. Siryk, Z., Popadynets, N., Pityulych, M., Chakii, O., Irtyshcheva, I., Panukhnyk, O., ... \& Lysyak, N. (2021). Decentralization of local self-government under the conditions of administrative-territorial reform in Ukraine. Accounting, 7(4), 781-790. https://doi.org/10.5267/j.ac.2021.2.006

[12]. Skydan, O., Budnik, O., \& Sus, L. (2021). The role of agroholdings in the creation of cooperatives by rural communities. Agricultural and Resource Economics: International Scientific EJournal, 7(1868-2021-1457), 107-122. https://doi.org/10.51599/are.2021.07.03.07.

[13]. Storonyanska, I., Dub, A., Grafska, O., Hrynchyshyn, I., Bilanyuk, O., \& Pierscieniak, A. (2021). The tourist infrastructure of local communities in Ukraine: current state and impact on local economic development. Agricultural and Resource Economics: International Scientific EJournal, 7(1868-2021-1378), 102-118. https://doi.org/10.51599/are.2021.07.02.06.

[14]. Horoshkova, L. A., \& Khlobystov, I. V. (2019). United territorial communities socio-economic development potential (The case of zaporizhzhia region). Ukrainian Geographical Journal,4(108), 18-27. https://doi.org/10.15407/ugz2019.04.018.

[15]. Umanets, L. (2019). Tools to increase the budget potential of amalgamated territorial communities. Scientific Horizons, 83(10), 51-57. https://doi.org/10.33249/2663-2144-2019-83-10-5157.

[16]. Wright, G., \& Slukhai, S. (2021). Decentralization Policy in Ukraine: How Voluntary Amalgamation, Inter-Municipal Cooperation and Fiscal Incentives Impacted the Local Government System. NISPAcee Journal of Public Administration and Policy, 14(1), 311-343. https://doi.org/10.2478/nispa-2021-0012.

[17]. Khirivskyi, R., Cherevko, H., Yatsiv, I., Pasichnyk, T., Petryshyn, L., \& Kucher, L. (2020). Assessment and analysis of sustainability of the socio-economic development of amalgamated territorial communities of the region. European Journal of Sustainable Development, 9(2), 569-569. https://doi.org/10.14207/ejsd.2020.v9n2p569

[18]. The experts analyzed the budgets of the united communities of each region for 2018 (2019), Retrieved from:

https://decentralization.gov.ua/news/10674 [accessed: 15 September 2021].

[19]. Estimation of financial indicators of budgets of 806 ATC. (2020). Rating for $2019 . \quad$ Retrieved from: https://decentralization.gov.ua/news/12192 [accessed: 18 September 2021].

[20]. Estimation of financial indicators of budgets 872 ATC. (2020). Rating for 9 months of 2020. Retrieved from: https://decentralization.gov.ua/news/12952 [accessed: 18 September 2021].

[21]. Estimation of financial capacity of 366 ATC for 2017 by regions. (2018). Retrieved from: https:/decentralization.gov.ua/uploads/library/file/18 3/366.pdf [accessed: 18 September 2021]. 